Revue d'histoire de l'Amérique française

RAS REVUE D.HISTOIRE DE L'AMÉRIQUE FRANÇAISE

\title{
« L’Affaire Dollard », de Fort Orange au Long-Sault
}

\section{Jacques Rousseau}

Volume 14, numéro 3, décembre 1960

URI : https://id.erudit.org/iderudit/302060ar

DOI : https://doi.org/10.7202/302060ar

Aller au sommaire du numéro

Éditeur(s)

Institut d'histoire de l'Amérique française

ISSN

0035-2357 (imprimé)

1492-1383 (numérique)

Découvrir la revue

Citer cet article

Rousseau, J. (1960). « L'Affaire Dollard ", de Fort Orange au Long-Sault. Revue d'histoire de l'Amérique française, 14(3), 370-377.

https://doi.org/10.7202/302060ar d'utilisation que vous pouvez consulter en ligne.

https://apropos.erudit.org/fr/usagers/politique-dutilisation/ 


\section{"L'AFFAIRE DOLLARD », DE FORT ORANGE AU LONG-SAULT}

La Revue canadienne de Géographie accomplit un excellent travail, et sur un plan scientifique élevé. Comme président d'honneur, à l'ombre de l'éminent Raoul Blanchard, je serais mal venu de la critiquer. Cependant, on peut douter que la Rédaction ait eu la main heureuse récemment en publiant deux articles sur l'exploit de Dollard. ${ }^{1}$ Le sujet relève strictement de l'histoire et son unique lien avec la géographie réside dans le fait qu'une action a nécessairement lieu en un point donné. Il n'est pas anormal toutefois qu'un périodique sorte à l'occasion de son champ d'intérêt, mais alors les risques d'errer augmentent. Il y a néanmoins de quoi étonner quand un auteur adresse ses commentaires historiques à une revue de géographie plutôt qu'à une revue d'histoire.

Toutes les facettes de «l'affaire Dollard» ont retenu mon attention. Avec un «homme de rivière » et mon fils, j'ai même sauté le Long-Sault, glissant en chaloupe dans le «passage infaillible »,2 l'unique chemin fluide des voyageurs descendant la rivière Outaouais. Je suis plutôt un coureur des bois qu'un historien, et j'ai vu parfois dans la nature des problèmes du passé replacés dans leur contexte. L'écologie humaine, elle aussi, se place parmi les sciences auxiliaires de l'histoire. Pour reconstituer la vie des Amérindiens, des découvreurs, des trafiquants de fourrures, des premiers colons, la connaissance approfondie du milieu fournit des indices précieux, absents des documents, et sans lesquels les discussions restent oiseuses.

Si l'on considère le combat de Dollard sous cet angle, on en arrive à des solutions qui ne concordent pas toujours exactement

1 Revue canadienne de Géographie (1959), 13: 190-196. Les deux articulets, du même auteur et sur le même sujet, portent les titres de «La redoute de Dollard, à la baie des Sauvages» et «Un fort défendu par dix-sept Français ».

2 Le mot est de Dollier de Casson. 
avec celles que l'on présente d'habitude. Néanmoins, les variantes portent seulement sur des points secondaires, - le trajet suivi et le site précis de l'exploit —; l'essentiel reste intouché.

Pourquoi le lieu de l'événement ferait-il l'objet d'une controverse passionnée ? Comme dirait La Palisse, Dollard et ses compagnons sont morts où on les a tués. Voilà un fait certain où les sentiments ne devraient pas entrer en cause. Nous savons que le massacre eut lieu au Long-Sault, mais cela, sur le terrain, laisse encore une certaine marge. Jusqu'ici, on a recherché le site précis de façon plutôt objective. Des éléments de preuves ont pu favoriser un endroit ou l'autre; certains n'ont pas résisté à la critique. Seules des fouilles archéologiques, faites à la lueur des documents anciens et de la connaissance de la nature, pourront peut-être élucider le problème.

Sur les indications de Mlle Anne F. Dewar, ${ }^{3}$ monsieur Thomas $\mathrm{E}$. Lee, archéologue des plus compétents et des plus consciencieux, entreprit des fouilles en 1951. Elles furent abandonnées par la suite; je contribuai pour ma part à les remettre en marche. D'après monsieur Lee, - et je suis de son avis - les données présentes désignent un endroit comme le lieu le plus vraisemblable de l'exploit de Dollard; mais les fouilles toutefois ne sont pas terminées. D'autres sites aussi doivent être étudiés et alors seulement l'on pourra se faire une idée plus précise de la question.

Une solution définitive à la veille du troisième centenaire, certes, eût été intéressante. Hélas, la vérité ne sort pas du puits à échéances fixes. L'histoire se soucie peu du «scoop » journalistique; elle admet encore moins les opinions irrévocables. Elle table uniquement sur les faits. Dans l'un des articulets cités de la Revue canadienne de Géographie, une argumentation assez discutable met au crédit de l'auteur des recherches poursuivies par d'autres. Vient ensuite cette conclusion magistrale:

A ces témoignages, ajoutons que l'affaire Dollard des Ormeaux est pour nous tirée au clair. ${ }^{4}$

3 Habitant la région d'Argenteuil, Mlle Dewar avait recueilli sur la rive québécoise de l'Outaouais la tradition voulant que l'exploit de Dollard ait eu lieu de l'autre côté de la rivière.

${ }^{4}$ Rev. can. Géog., 13: 193. 
Déjà, Lafontaine avait mis en relief le laborieux travail de la mouche du coche.

Il est prématuré de vouloir trancher le problème du site. Aussi, je m'attarderai plutôt à certaines inexactitudes (pour employer un euphémisme) relevées dans le texte qui fait état d'un rapport du vice-directeur du poste de Fort Orange à ses supérieurs, en 1660 . On nous présente ainsi cette nouveauté:

Une brève chronique au sujet du combat de Dollard des Ormeaux avec une bande d'Iroquois au Long Sault a jusqu'ici passé inaperçue, dans les annales de la compagnie hollandaise de la traite des fourrures à Albany. 5

A la lecture, on pourrait croire le document inédit, et pourtant il a été publié à Albany il y a environ 80 ans et, plus près de nous, Léopold Desrosiers l'a cité en $1945 .^{6}$

Le rapport, évidemment, méritait d'être relevé de nouveau, mais il ne pouvait conduire aux conclusions sommaires qu'on nous présente. De la traduction anglaise de la longue lettre de La Montagne, il n'est cité que quatre lignes. Pour éviter les contresens d'un extrait séparé de son contexte, j'ai cru utile de publier la pièce au complet, telle qu'elle paraissait dans le volume où l'a prise le commentateur extraordinaire de la Revue canadienne de Géographie. ${ }^{7}$

Letter from Vice D'r La Montagne at Fort Orange to Dir. Stuyvesant and Council; Indian brokers; Mohawks and Senecas cut off a French Fort.

Honorable, Valliant and Worshipful Gentlemen.

Having left you, gentlemen, on the $14^{\text {th }}$ of May last I arrived here Friday the $21^{\text {th }}$ of the same month

5 Rev. can. Géog., 13 : 193

6 Léopold Desrosiers, «Dollard des Ormeaux dans les textes », Cahiers des Dix, Vol. 10 (Montréal 1945).

$7 \mathrm{~B}$. Fernow, Documents relating to the history and settlements of the towns along the Hudson and Mohawk rivers (with the exception of Albany) from 1630 to 1684 . And also illustrating the relations of the settlers with the Indians. Translated, compiled and edited from the original records in the office of the secretary of state, at Albany, and other sources (Albany, N.Y. Weed, Parsons and Company, 1881) - (Voir p. 175). Cet ouvrage fait partie de la série intitulée « Documents relating to the colonial history of the state of New York 》, vol. 13. 
at night, since which time I have had no opportunity, nor even leisure to answer the objections made by Mr. van Ruyven to my accounts. On the Monday following my return my wife's sister was by an accident mortally (as we then thought) wounded, Tuesday the Commisaries met to dispose of more than forty cases and a petition by the principal traders of this place was handed in against the placat issued by his Honor the Director-General and Council and since republished annually, that only Indian brokers should be admitted to carry on the trade. After the bench had taken this into consideration, it was ordered to call the whole community into the fort, to learn their opinion on this matter. They assembled on Wednesday and having been heard individually they expressed a different opinion, viz that it would be better, to give the enormous amount of brokerage, which went now yearly into the pockets of the Indian brokers - about fifty thousand guilders - to Dutchmen. As this opinion went directly against the request of the petitioners, the latter, increased to twenty-five altogether, presented Wednesday a second petition, repeating their former demands. Friday the other, small traders, also presented a petition signed by fifty-four persons and now they began to scold and call each other bad names and threats were uttered: Saturday the Court was convened to deliberate how to settle this matter, in which the parties were so bitter and hostile against each other: the Court could not come to any conclusion and on that account was adjourned over till Monday, when the Court, having assembled, decided to deny the petitions of either party and ordered that in accordance with the placat neither Dutch nor Indian brokers should be employed during the trading under a penalty of 300 guilders and suspension from their pursuits for the time of two months.

Since that time I have been obliged to go into the woods with soldiers to prevent mishaps and to see that the ordinances are observed. It comes very hard upon me, as I have no deputy sheriff, and it has gone so far, that I must frequently remain over night in the woods: that is the reason, why I have until now been unable to answer the objections to my accounts and to bring or send them: they will be 
brought down by me or by Johannes Provost in the next sloops.

Nothing new concerning the savages has happened here, except that the Maquas and Sinnekus, six hundred strong, have attacked a fort, defended by seventeen Frenchmen and one hundred savages: they overpowered the garrison and put them all to death with the exception of two Frenchmen and twenty savages, whom they carried as prisoners back to their fort; they have lost fourteen killed; nineteen were wounded. ${ }^{8}$ Hoping shortly to have the pleasure of seeing you or sending you my regards through Johannes Provost I remain meanwhile

Your Honor's obedient servant

15 June 1660

La Montagne

L'original, conservé à Albany, ${ }^{9}$ est en hollandais. J'en possède une copie photographique depuis l'époque où j'ai commencé à m'occuper activement du problème Dollard. En voici le dernier paragraphe, avec une traduction littérale en anglais:

[Texte original hollandais]: Hier is tot noch toe weijnig nieuws aengaende wilden voorgevallen anders als dat de Maquaessen en Sinnekus seshondert sterck sijnde, een fort geattaqueert hebben -, in welcke wonen 17 francen en hondert wilden welcke gewonnen hebbende hebben sij die alle dootgeslagen op 2 francen en 20 wilden die sij gevangen in haer fort bebracht hebben, van haer sijn doot gebleven 14 en 19 gequetst. Hoopende de Heeren [sigle d'interprétation difficile] den naesten te groeten in persoone off door Johannes Provoost sal Ick ondertuschen blijven

In de fort Orange den 15 Junij $A^{\circ} 1660$

$\mathrm{U}: \mathrm{E}: \mathrm{D}:$ ootmoedighe ende, goetwillige dienaer La Montagne.

[Traduction littérale]: Little new concerning savages has happened here as yet except that the Maquas and Sinnekus being six hundred strong, have attacked a fort in which live 17 frenchmen and one

8 En italique, la seule partie du texte reproduite dans l'article de la Rev. can. Géog.

9 N.Y. Col. Mss. v. 13: 114. The New York State Library (The University of the State of New York), Albany, N.Y. 
hundred savages having overpowered them, they beat them all to death except 2 frenchmen and 20 savages which they carried as prisoners to their fort, of themselves remained dead 14 and 19 wounded. Hoping shortly to greet the Gentlemen in person or through Johannes Provoost, I shall remain meanwhile 10

In the Fort Orange Your honorable gentlemen's on the $15^{\text {th }}$ of June Anno 1660.

Humble and villing servant

La Montagne.

En somme, que raconte La Montagne ? La même chose que Marie de l'Incarnation, les missionnaires jésuites Chaumonot et LeJeune, le sulpicien Dollier de Casson, le coureur des bois PierreEsprit Radisson, et que répètent depuis lors tous les historiens. Comme certains esprits «évolués » veulent faire croire que l'épisode du Long-Sault est un conte inventé par de « pieux personnages » du Québec, ${ }^{11}$ le document émanant du centre protestant de Fort Orange a certainement quelque poids, puisqu'il confirme les versions canadiennes.

Toutefois, le «découvreur» $d u$ rapport, pour minimiser «l'affaire », y va de ses propres opinions qu'il tente d'imputer à La Montagne:

L'épisode ci-dessus de la bataille des dix-sept Français barricadés et la mort de tous sauf deux qui

$10 \mathrm{Je}$ remercie mon collègue F. A. Stafleu, de l'Université d'Utrecht, Pays-Bas, qui a eu l'obligeance de transcrire le manuscrit hollandais et d'en faire la traduction littérale. La lettre est écrite en scripts gothiques, sauf la ligne de salutations à la fin, en scripts hollandais sensiblement l'équivalent de notre italique. Ont également collaboré à la transcription de mots litigieux mon collègue G. M. Schulzes, du Jardin botanique de Berlin-Dahlem, le directeur Dr Zimmermann et Dr Bleich, paléographes des Archives de Berlin-Dahlem, et également Prof. van den Kerckhove, de la chaire de néerlandais de l'Université libre de Berlin-Dahlem. D'après M. Stafleu le script gothique, inusité en hollandais, offrait moins de prises aux indiscrétions des messagers. Le texte n'émane pas d'une personne parlant correctement le hollandais et les fautes ne sont pas non plus d'un germanique. Il y a tout lieu de croire à l'origine française de La Montagne. On sait le rôle des guerres de religion en France. L'édit de Nantes, promulgué en 1598, n'a été révoqué qu'en 1685, mais dès 1631 commencèrent les restrictions provoquant déjà une émigration vers les pays germaniques. On peut se demander si La Montagne n'aurait pas été l'un de ces exilés volontaires.

11 J'arrive difficilement à classer mon ancêtre Radisson dans une confrérie pieuse! 
furent ramenés captifs par les Mohawks en mai ou en juin 1660, passèrent presque inaperçus au pays des agresseurs iroquois. C'est qu'il n'y a là rien d'inaccoutumé. Mais il fut rapporté par lettre aux traitants hollandais d'Albany par le secrétaire canadien de langue française en leur Conseil, Wm. De La Montagne. La nouvelle avait dû lui en être communiquée par les survivants vainqueurs au Long Sault, dès leur retour chez eux. Après toutes ces escarmouches, les Iroquois se hâtaient toujours de retourner parmi les leurs avec leur butin, pour pleurer leurs morts, torturer leurs prisonniers, et festoyer à leur manière. Toujours est-il que le rapporteur De La Montagne ne fait pas grand état de la nouvelle, qui semble lui avoir parue normale...

[Et plus loin] : Le peu de cas que fit De La Montagne de cet incident démontre bien l'absence de tout élan patriotique et national tel qu'il inspire les autres relations, à Montréal et à Québec.12

Comment celui qui a écrit les lignes ci-haut, peut-il affirmer si catégoriquement que l'événement "est passé presque inaperçu en pays Iroquois»? Comme nous tous il n'en sait absolument rien, sauf que les guerriers iroquois en ont parlé à Fort Orange.

Et quelle est cette trouvaille que La Montagne est «le secrétaire canadien de langue française du Conseil hollandais »? Fort Orange, ennemi juré de la Nouvelle-France, armant les Iroquois contre la colonie du Saint-Laurent, aurait eu un secrétaire canadien dans son Conseil! Cela serait si surprenant, si insolite, si étrange, qu'une simple affirmation ne tient pas debout sans preuve à l'appui. Cette naturalisation canadienne avant la lettre du commerçant La Montagne tente-t-elle simplement de démontrer que nos ancêtres s'intéressaient peu à «l'affaire»?

Pourquoi faudrait-il que le même événement provoque «le même élan patriotique » à Fort Orange que chez les adversaires de Montréal et de Québec ?

Est-il prouvé pour autant que «La Montagne fit peu de cas de l'incident ». $\mathrm{Au}$ lieu d'un texte tronqué, relisons la lettre entière, en gardant présent à l'esprit que c'est un gérant de poste

12 Rev. can. Géog. (1959), 13 : 195-196. 
qui écrit à ses supérieurs pour les renseigner sur ce qui se passe à leur comptoir de Fort Orange. Sauf une brève mention d'ordre familial, il se limite à ce qui les intéresse, c'est-à-dire ce qui touche de près ou de loin à leur commerce. Dans cette optique, il raconte l'histoire du Long-Sault, se bornant à relater sans commentaires le témoignage iroquois. Ce qui arrive en NouvelleFrance ne le préoccupe pas, sauf si cela risque d'affecter le troc des fourrures. Et s'il prend la peine de signaler le combat, c'est uniquement parce qu'il pressent là un événement assez important pour perturber le commerce hollandais.

Ayant vécu avec des gérants de poste à des centaines de milles de la civilisation, je connais assez leur état d'esprit. A leur côté, j'ai passé déjà des jours entiers à manipuler des pelleteries. J'ai aussi fouillé les archives d'Europe et d'Amérique pour ressusciter l'atmosphère des postes d'autrefois. J'ai tenté de suivre à la trace le trafiquant de la Ferme du Roi et des compagnies étrangères. Et cela me permet de conclure que La Montagne a parlé de l'exploit uniquement parce qu'il l'a jugé important. Celui qui manie gauchement la plume, avec des doigts usés par la fourrure et engourdis par la hache ou l'aviron, ne se livre guère au potinage épistolaire. Il s'en tient strictement aux nouvelles de son métier.

J'ai cherché les points faibles du dossier Dollard. Pour ceux qui ont étudié tous les documents sans parti pris, Dollard est un héros, comme Jogues et Brébeuf. Et cela comprend les historiens anglo-protestants qui pourtant n'ont pas pour mission d'exalter les gloires des ennemis ancestraux. Une action d'éclat, comme celle du Long-Sault, eut-elle été de fétichistes dahoméens, ne peut commander que le respect.

Étrange tout de même cette opposition systématique qui épargne Laura Secord, Paul Revere et tant d'autres. Je crois avoir trouvé la faille: Dollard et ses compagnons seraient allés communier avant de partir pour le Long-Sault. Et cela rend leur aventure très suspecte !

JACQUES ROUSSEAU, La Sorbonne. 